\title{
Building wall corner structures, its microclimate and seismic resistance
}

\author{
Akymbek Abdykalykov ${ }^{1}$, Erkin Boronbaev ${ }^{1 *}$, Ulukbek Begaluev ${ }^{2}$, Kamoliddin Holmatov $^{1}$ \\ and Nurbubu Zhyrgalbaeva ${ }^{1}$ \\ ${ }^{1}$ Kyrgyz State University of Construction, Transportation and Architecture named after N. Isanov, \\ Departments: Production and expertize of building materials and constructions (an author 1), Heat- \\ Gas supply and ventilation; 720020, 34 b, Maldybaev str., Bishkek, Kyrgyzstan \\ ${ }^{2}$ International University of Innovation Technologies, Institute of construction and innovative \\ technologies; 720048, 1/17, Ankara str., Bishkek, Kyrgyzstan
}

\begin{abstract}
Widespread low-rise residential buildings with a seismically resistant concrete frame and brick infill walls have lower microclimate levels in cold seasons due to low temperatures on the inner wall corner surfaces.These temperatures are lower if there is a corner column. For Bishkek, this temperature is $4.6{ }^{\circ} \mathrm{C}$ lower than that for permissible microclimate, even when the external wall has the required $70 \mathrm{~mm}$ of mineral wool slab insulation. It is caused by the negative effect of the wall corner thermal bridge. This effect is determined by ArchiCAD 20 software packages by visualizing the temperature distribution in the cross-section of the corner, which needs an additional thermal insulation layer of $40 \mathrm{~mm}$. Using the LiraSAPR 2013 software package, the authors reduced the square cross-section dimensions of the column by $40 \mathrm{~mm}$ to allow for that additional thermal insulation layer. The optimal width of this layer is determined for different options for the meeting angle of two external walls from $70^{\circ}$ to $180^{\circ}$. For a typical $90^{\circ}$ angle, an acceptable width is 860 $\mathrm{mm}$. With this insulation, it is possible to achieve the required temperature at the corner. The authors eliminated the negative thermal effect of the corner by rounding it with cement-sand plaster. Using the isotherms, it was determined that the rounding radius of $300 \mathrm{~mm}$ allowed for equal temperatures on the corner and inner surface of the external walls. The achieved results show that the microclimate formed as in a room without external wall corners.
\end{abstract}

The main purpose of the work is to study and solve the problem of creating appropriate corner structures of buildings to ensure the required standards for microclimate and seismic resistance.Considering the features of buildings located far from the equator and in mountainous regions, the authors concluded that the structural solutions of the corners of the outer walls require comprehensive consideration and improvement. The urgency of this task is because in these regions a large number of people live in poorly studied low-rise buildings.

In addition, most of the populations with insufficient incomes have homes with low levels of microclimate and seismic resistance.

\footnotetext{
* Corresponding author: boronbaev@elcat.kg
} 
In the mountainous regions of Central Asia, there are buildings with unreasonably high seismic resistance due to the fact that they are often designed without seismic resistance calculations. On the other hand, external building enclosures have disadvantages resulting in low indoor thermal comfort and higher financial heating costs.

The authors found that the existing low-rise concrete frame residential buildings are built with an unjustifiably large cross-section of columns, which create a negative effect of thermal bridges [1]. The under investigation an external walls corner is a complex combination of two types of thermal bridges: 1 - the outer corner is an architectural thermal bridge; 2 - built-in reinforced concrete corner column - constructive thermal bridge, since the column material has high thermal conductivity. These structures lead to the appearance of mold [2, 3, 4] and worsen the indoor microclimate and sanitary-hygienic conditions [5].The connections of the external walls to the reinforced concrete column [6] and the corners of the external walls lead to a decrease of temperature on the corresponding inner surface $[7,8]$.To prevent such negative consequences, it is required to provide a layer of thermal insulation on the external side of these surfaces [9].

Numerical studies based on the use of the LiraSAPR 2013 and ArchiCAD 20 software packages were taken as a method for studying the problem and achieving the goal.

The first package made it possible to determine the appropriate dimensions of the crosssection of the columns and crossbars of a monolithic seismic-resistant reinforced concrete frame of a two-story brick building. The second package was used for a study of the temperature distribution on the cross-section of the corner structure of the external walls with a reinforced concrete corner column.

To present the research results, the graphic-analytical method and the method of visualizing isotherms and heat flows were used for various constructive solutions of the external wall corner. A typical example of a two-story residential building was adopted as the object of research (Fig. 1).

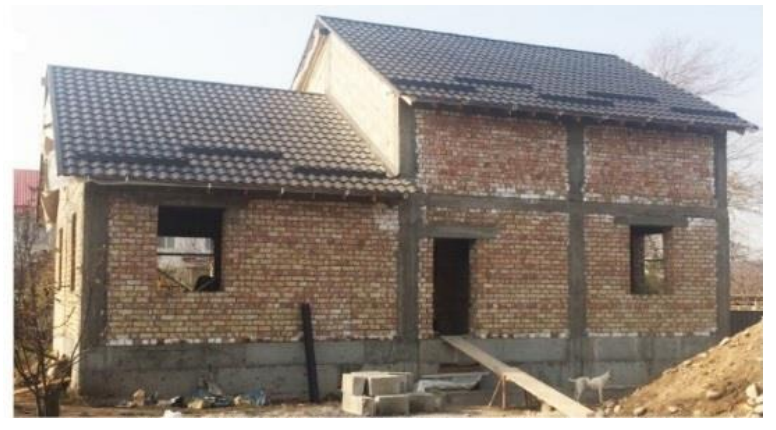

Fig. 1. Exterior view of the existing residential building on address: 40, Kozhomkul str., Bishkek, Kyrgyzstan

The calculation for seismic action was carried out for a critical combination of loads using the LiraSAPR 2013 software package with seismicity in Bishkek of 9 point on the MSK-64 scale. Schemes for calculating the seismic resistance of the building (see Fig. 1) is shown in Fig. 2.

A multivariate calculation was performed for: 1 . the size of the cross-section of columns and crossbars, $380 \times 380 \mathrm{~mm}$, with the reference thermal protection capacity of the external walls; 2. the same, at $340 \times 340 \mathrm{~mm}$, and with an additional layer of thermal insulation and without it $[3,10]$. The calculation results are presented in Table 1. 
a)

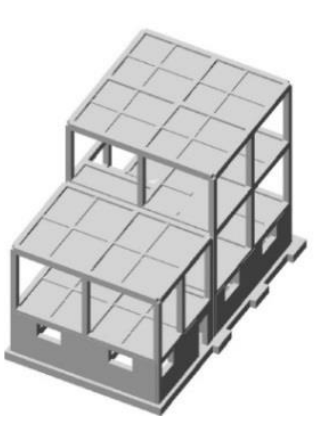

b)

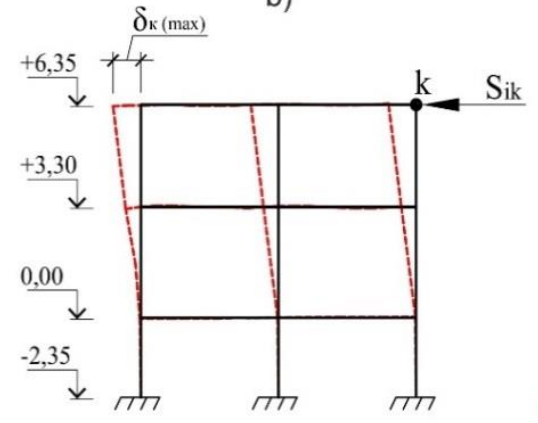

c)

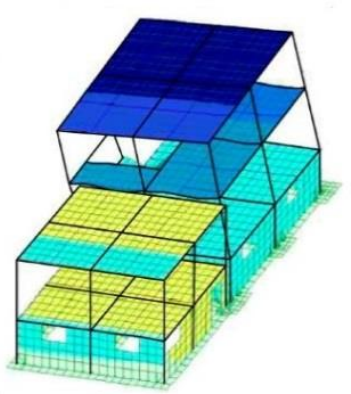

Fig. 2. Schemes for calculating the seismic resistance of a two-story residential building: a) spatial model of the building; b) movement of the constructive frame of the frame under seismic load $\mathrm{S}_{\mathrm{ik}} ; \mathrm{c}$ ) building deformation.

Table 1. The results of seismic resistance calculations of a building with two constructive solutions for the external wall corner

\begin{tabular}{|l|c|c|}
\hline \multicolumn{1}{|c|}{ Indicators } & $\begin{array}{c}\text { With main insulation } \\
\text { (column 380x380 mm) }\end{array}$ & $\begin{array}{c}\text { With main and } \\
\text { additional insulation } \\
\text { (column 340x340 mm) }\end{array}$ \\
\hline Movement $\delta_{\mathrm{K}(\max ),}, \mathrm{mm}$ & $10,56<31,75$ & $13,12<31,75$ \\
\hline $\begin{array}{l}\text { The accepted percentage of } \\
\text { reinforcement for columns } \mu, \%\end{array}$ & $2,19<6$ & $3,04<6$ \\
\hline $\begin{array}{l}\text { The accepted percentage of } \\
\text { reinforcement for crossbars } \mu, \%\end{array}$ & $1,61<4$ & $2,32<4$ \\
\hline
\end{tabular}

In result, it was found that with a frame cross-section of $380 \times 380 \mathrm{~mm}$, the building (see Fig. 1) has a significant margin of seismic resistance: the maximum moving $\delta_{\mathrm{K}}(\max )$ of the upper zone of the building is $10.56 \mathrm{~mm}$, which is lower than the maximum permissible $31.75 \mathrm{~mm}$ (according to the norms of SP 20.13330.2011, Loads and Impacts. Updated version of SNiP 2.01.07-85*). The percentage of column reinforcement is $2.19 \%$, which is below the limit value of $6 \%$ (for crossbars, this indicator is $1.61 \%$, which is below the limit value of $4 \%$ ). When the cross-sectional dimensions of the frame elements are reduced to $340 \times 340 \mathrm{~mm}$, the specified maximum movement is $13.12 \mathrm{~mm}$, and the percentage of reinforcement for the columns is $3.04 \%$ (for - crossbars $2.32 \%$ ). Accordingly, it is proposed to take the reduced dimensions of the cross-sections of the frame elements of 340x340 mm with a significant margin of seismic resistance of the building.

The ArchiCAD 20 software package allows the study of the peculiarities of thermal bridges in the enclosures [11] using the isotherms [2, 6, 8, 12]. The authors carried out research on the basis of isotherms on the cross-section of the constructive solutions of the external wall corner.

The calculations of the heat protection capabilities of the external wall were made (according to SP 50.13330.2012. Thermal protection of buildings. Updated edition of SNiP 23-02-2003) under these conditions: a brick wall has $\delta=380 \mathrm{~mm}$, thermal conductivity coefficient $\lambda=0.81 \mathrm{~W} /\left(\mathrm{m} \cdot{ }^{\circ} \mathrm{K}\right)$; reinforced concrete columns $\delta=380 \mathrm{~mm}, \lambda=2.04$ $\mathrm{W} /\left(\mathrm{m} \cdot{ }^{\circ} \mathrm{K}\right)$; cement-sand plaster $\delta=20 \mathrm{~mm} ; \lambda=0.93 \mathrm{~W} /\left(\mathrm{m}^{\circ}{ }^{\circ} \mathrm{K}\right)$; mineral wool slabs with a 
density $\rho=75 \mathrm{~kg} / \mathrm{m}^{3}$ and $\lambda=0.04 \mathrm{~W} / \mathrm{m}{ }^{\circ} \mathrm{K}$ ).It should be noted that calculations based on SNiP KR 23-01: 2013. Thermalprotection of buildings* give the same results.

The results of modeling the heat transfer processes of the corner zone of external walls in the form of a colored fill of the heat flow and isotherms are shown in Fig. 3.
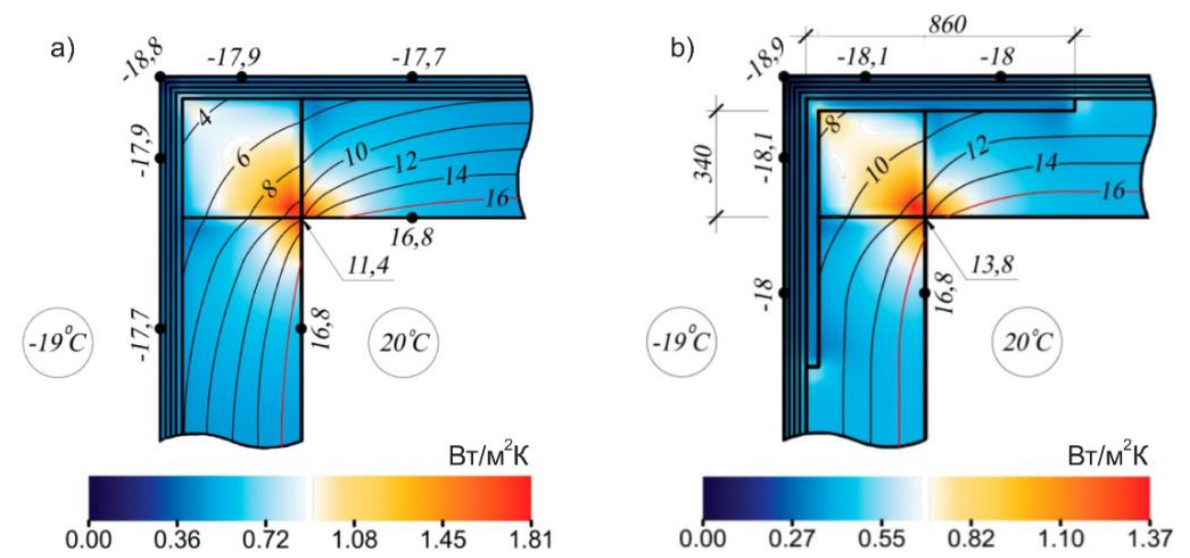

Fig. 3. Heat flow and isotherms at the section of the external wall corner of the building (according to Fig. 1): a) heat flow and isotherms with the reference (hereinafter: main) layer of thermal insulation; b) the same, with the main and additional layer of thermal insulation

With the reference main layer of thermal insulation $70 \mathrm{~mm}$ thick, the temperature on the corner is $11.4^{\circ} \mathrm{C}$ (Fig. 3, a). The difference $\Delta \mathrm{t}$ between this temperature and the air temperature in the room $\left(20^{\circ} \mathrm{C}\right)$ is $8.6^{\circ} \mathrm{C}$, which is higher than $4{ }^{\circ} \mathrm{C}$ allowable by SP $\mathrm{KR}$ 23-101-2013. Thermal performance design of buildings*.For this reason, it is proposed to arrange an additional $40 \mathrm{~mm}$ thick layer of thermal insulation on the external side of the corner zone (see Fig. 3, c) when column cross-section is reduced to $340 \times 340 \mathrm{~mm}$.

The authors investigated the dependence of the temperature on the inner surface of the corner zones ti on both the angle $\alpha$ of the meeting of the external walls and the width A of the additional layer of thermal insulation. The conditions of heat transfer processes were studied when changing A from 0 to $1120 \mathrm{~mm}$, as well as the angle $\alpha$ from $30^{\circ}$ to $180^{\circ}$ (Fig. 4). It was that, when all other things being equal, on sharp corners of the external walls, the temperature ti is significantly lower than at obtuse corners. This temperature ti at a wall angle of $70^{\circ}$ (scheme a, Fig. 4) has a lower value than at a wall angle of $160^{\circ}$ (scheme c, Fig. 4). For the case of a usual $90^{\circ}$ angle (scheme c, Fig. 4), when the width of the additional thermal insulation layer changes above $860 \mathrm{~mm}$, the temperature on the corner remains constant. With this width, the above temperature difference $\Delta \mathrm{t}$ is equal to $6.2{ }^{\circ} \mathrm{C}$ (see Fig. 3, b), which is also higher than the standard $4{ }^{\circ} \mathrm{C}$. In works $[1,13]$, to reduce the temperature difference $\Delta \mathrm{t}$, it is proposed to round the inner corner of the external walls with a cement-sand mortar.

To determine the required geometric characteristics of such rounding, the authors carried out numerical investigations of the dependence of the temperature ti on the radius $\mathrm{R}$ of the rounding made on a fragment of a circle inscribed in a corner (Fig. 5).

* The author E. Boronbaev is a member of the development team of these two national codes. 


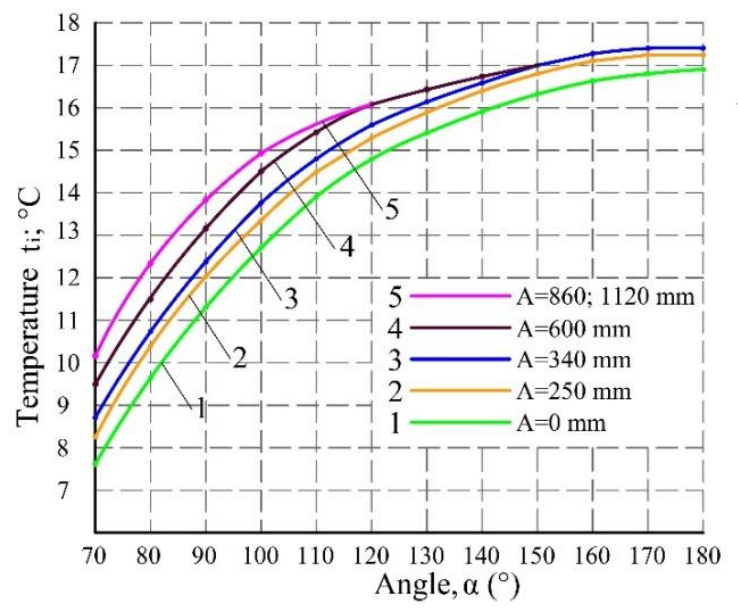

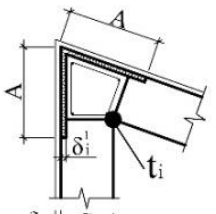

a)

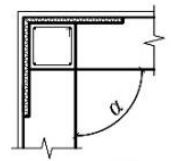

b)

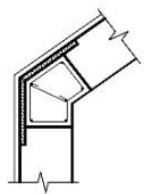

c)

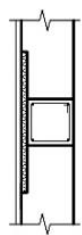

d)

Fig. 4. Dependence of the temperature on the corner t from the meeting angle of the walls $\alpha$ and the width of the additional thermal insulation layer A.

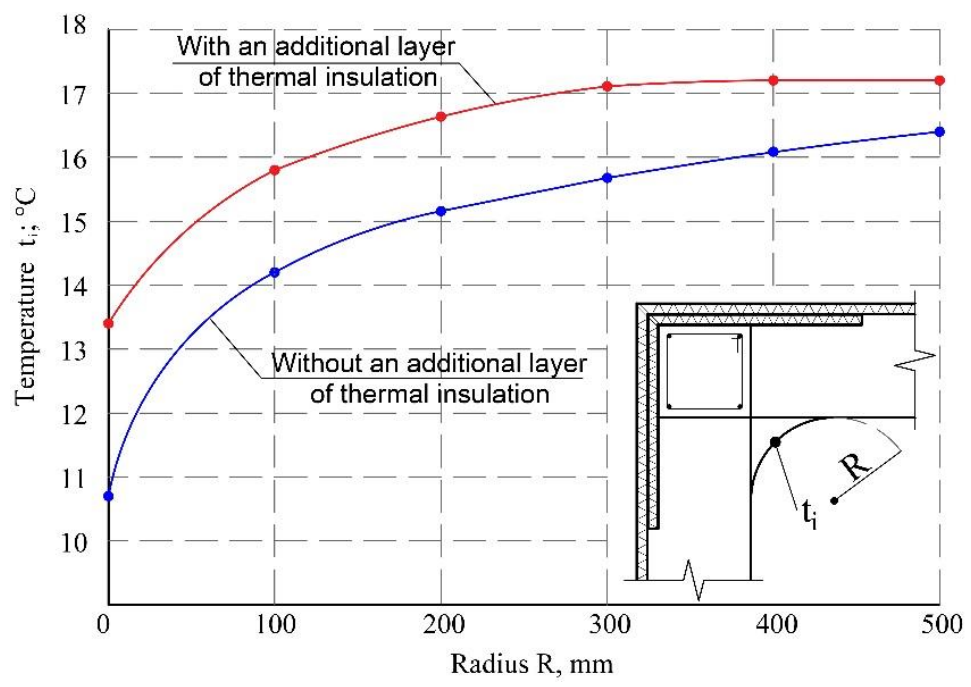

Fig. 5. Graph of the dependence of the temperature on the inner surface of the corner on the rounding radius $\mathrm{R}, \mathrm{mm}$

It resulted that with the thickness of the additional layer of thermal insulation made of mineral wool slabs $40 \mathrm{~mm}$ thick and $860 \mathrm{~mm}$ wide, with a rounding radius of $300 \mathrm{~mm}$ and more, the temperature on the corner is maximum and equal to $17.1{ }^{\circ} \mathrm{C}$ (see also Fig. 6 , a). In the absence of this rounding, the maximum possible temperature is reached at $\mathrm{R}$ of about $610 \mathrm{~mm}$. At this temperature on the surface of the rounding center the temperature difference is $\Delta \mathrm{t}=2.9^{\circ} \mathrm{C}$, which is lower than the normative permissible one, equal to $\Delta \mathrm{t}=4$ ${ }^{\circ} \mathrm{C}$, according by requirements of SP 50.13330. 2012 and SP KR 23-101-2013. The results obtained also satisfy the requirements of ISO 10211: 2007 [14]. On the basis of the obtained research results, control calculations were carried out and acceptable temperatures were achieved for the external walls corners of buildings in various climatic conditions. 

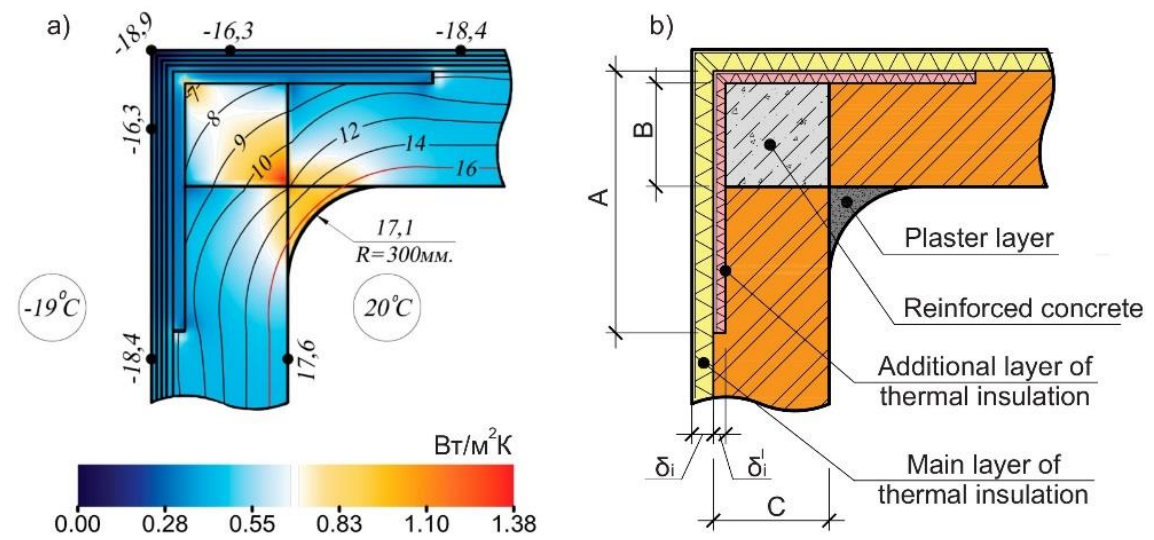

Fig. 6. Proposed wall corner construction: a) isotherms on the cross section of the corner; $b$ ) a cross section of the proposed corner construction.

The practical use data of the proposed corner construction in the cities of Russia, Kyrgyzstan and Tajikistan presented in Table 2.

Table 2. Data on the practical use of the proposed constructive solution for the external wall corner of buildings in cities with different climatic conditions

\begin{tabular}{|c|c|c|c|c|c|c|c|}
\hline \multirow{2}{*}{ City names } & \multicolumn{6}{|c|}{ Recommended dimensions, mm } & $\begin{array}{c}\text { Temperature, } \\
{ }^{\circ} \mathrm{C}\end{array}$ \\
\hline & C & $\mathbf{A}$ & B & $\mathbf{R}$ & $\delta_{i}$ & $\delta_{i}^{1}$ & $t_{i}$ \\
\hline Magadan $(\mathrm{Ru}$ & \multirow{3}{*}{380} & \multirow{3}{*}{860} & \multirow{3}{*}{340} & \multirow{3}{*}{300} & 140 & \multirow{3}{*}{40} & 17,2 \\
\hline Naryn (Kyrgyzstan) & & & & & 100 & & 16,9 \\
\hline Dushanbe (Tajikistan) & & & & & 40 & & 17,2 \\
\hline
\end{tabular}

The results of using [15-18] for mathematical models of thermal processes in the zone of thermal bridges under various boundary conditions show that the numerical methods of research adopted by the authors led to good results. In works [19, 20], similar computer calculations were used. The authors of works [21, 22] also solved the problem of reducing the negative effect of thermal bridges. The results of the authors are based, as in $[23,24]$, on temperature distribution data, presented as isotherms, in the cross section of the thermal bridge zone.

The results of work [25] on the study of the influence of acute and obtuse corners of external walls are consistent with the results of this study. Like this study found, at obtuse wall corners, heat losses decrease and, as noted an author of [26], this shows the advantage of the external walls of the building in the form of a cylinder. According to the concept [27] proposed for the first time on the building form energy efficiency and its dimensionless relative indicator, such a cylindrical building has less heat losses than a cube-formed building, but much more than a "theoretical" building in the form of a sphere. The authors of [28], based on practice, also note that the heat losses of buildings depend on their spaceplanning characteristics.

In addition, the term and concept of energy-saving architecture, first published [29] by the author of works [1, 26, 30] in Prague (Czech Republic) in 1998, meet the modern challenges of climate change and are aimed at increasing energy efficiency of buildings, in 
particular, by reducing the number and negative impact of thermal bridges. These works indicate that the smallest number of thermal bridges is observed in buildings in the form of a national Kyrgyz yurt. The elimination of the thermal bridge effect of the external walls corners, achieved by the authors of this work, means that in a rectangular room with the proposed structure of corners, the microclimate is formed as in a cylindrical room.

The research results of the authors of this study are consistent with the theoretical ideas of the authors $[31,32]$ on the creation of such architecture of buildings, which is aimed to increase their energy efficiency and to reduce the rate of global climate change. Moreover, these results take into account the practical implementation of fundamental approaches, firstly, for the planning, design and creation of buildings with low energy consumption for heating, cooling, ventilation and lighting [31, 33, 34]; secondly, daily and annual the energy efficient interaction of the building [31] with the dynamic renewable energies of the environment and the incoming solar radiation.

\section{Conclusions}

1. For reference climatic parameters of Bishkek, the temperature on the inner surface of the external walls corner is $4.6{ }^{\circ} \mathrm{C}$ lower than the permissible one, even with the normative external thermal insulation of the wall layer of mineral wool slab on $70 \mathrm{~mm}$ due to the presence of a reinforced concrete corner column of the seismic resistant frame.

2. The corner thermal bridge effect was eliminated due to the seismically acceptable reduction of the square cross-section sides of the corner column by $40 \mathrm{~mm}$ and by an additional layer of external thermal insulation of the thermal bridge zones by mineral wool slab with the same thickness.

3. The optimal width of the additional layer of thermal insulation on the thermal bridge zones was determined by calculation and graphic means for various options of the angle of meeting of two external walls from $70^{\circ}$ to $180^{\circ}$. For Bishkek, at a typical $90^{\circ}$ angle, the required width is $860 \mathrm{~mm}$.

4. The negative thermal effect of the corner to the microclimate was proposed to be eliminated by rounding it with a cement-sand plaster. The isotherms of the conditions of Bishkek showed that with a rounding radius $300 \mathrm{~mm}$, the temperature on the corner surface is equal to the temperature on the main surface of the walls - the microclimate formed as in a room without external wall corners.

\section{References}

1. Э.К. Боронбаев, Вестн. КГУСТА, 4, 130-136 (2013)

2. T. Oreszczyn, Building Serv. Eng. Res. Technol., 9 (4), 167-175 (1988)

3. Э.К. Боронбаев, У.Т. Бегалиев, К.Н. Холматов, Вестн. КГУСТА, 4, 157-163 (2017)

4. Н.П. Умнякова, К.С. Андрейцева, В.А. Смирнов,Строит. и реконст.,6 (50), 53-64 (2013)

5. Т.С. Егорова, А.А. Федотова, П.Б. Белогуров,Кровель. и изол.матер.,4, 26-32 (2013)

6. D. Shaobin, Z. Yichao, H. Jun, N. Qingrong. Theopencivileng.jour.,9, 636-638 (2015)

7. Р.А. Назиров, В.С. Подковырин, К.А. Подковырина, Изв. вузов. Стр., 10-11, 106111 (2016)

8. A. Shybeka, D. Sakolchuk,Пробл. совр. бетона и железоб., 10, 93-102 (2018)

9. L. S. Paraschiv, S. Paraschiv, V. L. Lon,Intern. Scientific Conference "Environmental and Climate Techn.393-399 (2017) 
10. Э.К. Боронбаев, К.Н. Холматов,Наука, нов.техн. и инновац.Кыргызст., 2, 11-16 (2020)

11. М.А. Рылько. Пром. и гражд. стр., 4, 67-71 (2016)

12. M. Przemyslaw, L. Lech. The faculty of civil and envir.engin. and archit., 2, 8 (2018)

13. О.Д. Самарин. Пром. и гражд. стр., 8, 34-36 (2014)

14. EN ISO 10211:2007.Thermal bridges in building constructions - Heat flows and surface temperatures - Detailed calculations, 45 (2007)

15. S.J. Young, S.Ch. Gyoung, W.K. Kyoung, E.L. Seung,The heat transfer simulation for thermal bridge effect of the corner walls of building according to thermal condition, 169-174 (2007)

16. В.В. Лешкевич. Сист.анализиприкл. информ., 3, 26-30 (2015)

17. M. Orosz, J.E. Csanacy. Actatechnica Jaurinensis., 8 (3), 230-239 (2015)

18. A. Janssens, E. VanLondersele, B.Vandermarcke, S. Roels,Belgian build.researchinstit. and manager of EUROKOBRA EEIG, 10 (2007)

19. P. Tomas, P. Jan,Advanced mater.research, 649, 53-56 (2013)

20. K. Karabulut, E.Buyruk, A. Fertelli, Therm. science, 20 (1), 185-195 (2016)

21. M. Svitak., K. Krontorad, J. Tomek. Wood research ,61 (4), 607-614 (2016)

22. L. Moga, I. Moga.Journal of appl.engine. sciences., 5 (18), 65-71 (2015)

23. J. Hallik, T. Kalamees. A new method to estimate point thermal transmittance based on combined two-dimensional heat flow calculation, in the e3s-conference Proceedings of 12th Nordic Symposium on Building Physics (NSB 2020), 6-9 September 2020, Tallinn, Estonia. E3S Web of Conferences 172, 80050 (2020)

24. E. Boronbaev, B. Unaspekov, A. Abdyldaeva, K. Holmatov, N. Zhyrgalbaeva, Buildings enclosures coupling by its energy efficiency, seismic resistance and microclimate, in the e3s-conference Proceedings of XXIV International Scientific Conference on Construction the formation of living environment (FORM 2021), 22-24 April, 2021, Moscow, Russia (to be published in this issuer)

25. Ю. Толстова, Т. Харитонова. Сант.,отопл., кондиц., 8 (116), 52-53 (2011)

26. Э.К. Боронбаев, Вестн. КГУСТА, 4, 121-130 (2013)

27. Э.К. Боронбаев, Пробл. управл. и автомат., 449-455 (2000)

28. Т.В. Макарова. Е.А. Малиенко, Вестн. ВГАСУ, 1, 178-184 (2016)

29. Boronbaev E. Applied Optics and Solar Energy,Prague, 1, 296-299 (1998)

30. E. Boronbaev, Energy saving Architecture: Background, Theory and Practice in Kyrgyzstan, in the e3s-conference Proceedings of 12th Nordic Symposium on Building Physics (NSB 2020), 6-9 September 2020, Tallinn, Estonia, E3S Web of Conferences 172, $19010(2020)$

31. Э.К. Боронбаев, Повышение энергоэффективности зданий: предпосылки, теория, практика, Бишкек: Технология (2004)

32. S. Roaf, D. Crichton, F. Nicol, Adapting Buildings and Cities for Climate Change, London, New York: Elsevier (2009)

33. L. Norbert, Heating, Cooling, Lighting: Design methods for architects, New York: John Wiley and Sons, (2001)

34. L.D. Danny Harvey, A Handbook on Low-Energy Buildings and District-Energy Systems: Fundamentals, Techniques and Examples, London: Earthscan (2006) 